\title{
Shift-Share Analysis Revisited: The Allocation Effect and the Stability of Regional Structure
}

Henry W. Herzog, Jr.

Richard J. Olsen 


\section{DISCLAIMER}

This report was prepared as an account of work sponsored by an agency of the United States Government. Neither the United States Government nor any agency Thereof, nor any of their employees, makes any warranty, express or implied, or assumes any legal liability or responsibility for the accuracy, completeness, or usefulness of any information, apparatus, product, or process disclosed, or represents that its use would not infringe privately owned rights. Reference herein to any specific commercial product, process, or service by trade name, trademark, manufacturer, or otherwise does not necessarily constitute or imply its endorsement, recommendation, or favoring by the United States Government or any agency thereof. The views and opinions of authors expressed herein do not necessarily state or reflect those of the United States Government or any agency thereof. 


\section{DISCLAIMER}

Portions of this document may be illegible in electronic image products. Images are produced from the best available original document. 


\section{Printed in the United States of America. Available from National Technical Information Service \\ U.S. Departmont of Commerce \\ 5285 Port Royal Road, Springfield, Virginia 22161 \\ Price: Printed Copy $\$ 4.00$; Microfiche $\$ 3.00$}

This report was prepared as an account of work sponsored by the United States Government. Neither the United States nor the Energy Research and Development Administration/United States Nuclear Regulatory Commission, nor any of their employees, nor any of their contractors, subcontractors, or their employees, makes any warranty, express or implied, or assumes any legal liability or responsibility for the accuracy, completeness or usefulness of any information, apparatus, product or process disclosed, or represents that its use would not infringe privately owned rights. 
Contract No. W-7405-eng-26

SHIFT-SHARE ANALYSIS REVISITED:

THE ALLOCATION EFFECT

AND

THE STABILITY OF REGIONAL STRUCTURE

Henry W. Herzog, Jr.

Richard J. Olsen

\author{
Regional and Urban Studies Section \\ Energy Division \\ Oak Ridge National Laboratory \\ Oak Ridge, Tennessee 37830
}

Date Publiched - Auguot 1977

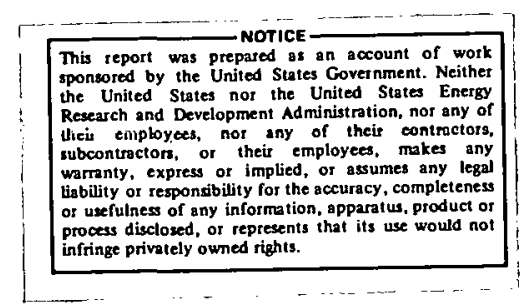

Work supported in part by the Regional Studies Program of the Energy Research and Development Administration's Division of Technology Overview under the Energy Research and Development Administration's subcontract with Union Carbide Corporation.

OAK RIDGE NATIONAL LABORATORY

Oak Ridge, Tennessee 37830

Operated by

UNION CARBIDE CORPORATION

for the

ENERGY RESEARCH AND DEVELOPMENT ADMINISTRATION

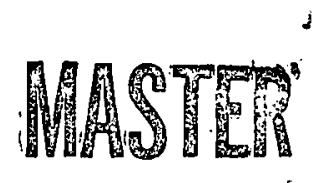




\section{THIS PAGE}

WAS INTENTIONALLY

LEFT BLANK 


\section{ACKNOWLEDGEMENT}

The authors wish to thank Lowell Ashby and Edgar Dunn, Bureau of Economic Analysis, U.S. Department of Commerce and Resources for the Future, Inc., respectively, for their helpful comments and suggestions. Any errors remain the responsibility of the authors. 
THIS PAGE

\section{WAS INTENTIONALLY \\ LEFT BLANK}




\section{TABLE OF CONTENTS}

Page

I. Introduction 1

II. The Classical Shift-Share Equation 2

III. Two Problems with the Classical Shift-Share Equation 4

A. The Problem of "Weights" 5

B. The Problem of "Interwoven Effects" 5

IV. A Proposed Reformulation 6

A. The Revised Equation 6

B. Analysis of Regional Employment Growth:
1960-1970

V. The problem of Weights Once Again 13

VI. Conclusions 21

$\begin{array}{ll}\text { Notes } & 22\end{array}$

$\begin{array}{ll}\text { References } & 23\end{array}$ 
SHIFT-SHARE ANALYSIS REVISITED: THE ALLOCATION EFFECT
AND THE STABILITY OF REGIONAL STRUCTURE

Henry W. Herzog, Jr.*

Richard J. Olsen**

\begin{abstract}
This paper examines the Esteban-Marquillas reformulation of the "classical" shift-share equation. The revised equation is used to decompose sectoral employment growth between 1960 and 1970 into four effects that measure differential change among U.S. regions. The empirical results indicate that this new technique expands the analytic properties of shift-share analysis, but that interpretations are sensitive to the temporal representation of regional structure in the shift-share equation.
\end{abstract}

*Assistant Professor of Economics, The University of Tennessee, Knoxville, and Consultant, Energy Division, Oak Ridge National Laboratory, Oak Ridge, Tennessee.

**Senior Research Associate, Charles River Associates, Inc., Cambridge, Massachusetts, formerly llead, Regional and Urban Studies Section, Energy Division, Oak Ridge National Laboratory, Oak Ridge, Tennesse日. 


\section{SHIFT-SHARE ANALYSIS REVISITED: THE ALLOCATION EFFECT AND THE STABILITY OF REGIONAL STRUCTURE \\ Henry W. Herzog, Jr., and Richard J. O1sen}

\section{Introduction}

The relationship between regional growth and industrial structure is often analyzed and decomposed into various "effects," with a technique known as shift and share analysis. Founded, perhaps, on Daniel Creamer's "locational shifts" in manufacturing [17], the technique was first developed and employed as an analytic tool during the early 1960's by Ashby [2], Dunn [6], Fuchs [8], and Perloff, Dunn, Lampard and Muth [12]. In recent years shift-share analysis and various transformations of the technique have been extensively employed by regional cconomists.

This paper examines a recent reformulation of the "classical" shift-share equation. The empirical results will show that this new technique expands the analyeic properties of shlft-share andidysis, but that interpretations are sensitive to the temporal representation of regional structure in the shift-share equation. In terms of the latter results, it will be shown that the attempt to correct one of the problems inherent in the original shift-share equation creates a related problem, of perhaps greater significance, in the transformed specification. 
II. The Classical Shift-Share Equation

The "classical" shift-share equation is designed to decompose the growth of a regional variable such as employment, income or output into three "effects" that measure differential growth among regions. Given. information by industrial sectors for one of these regional variables at two points in time, the technique divides the change, d, over the time period into the following effects: national growth, $g$, industry-mix, $m$, and competitive position, c. ${ }^{l}$ For industry section "i" in region "j":

$$
d_{i j}=g_{i j}+m_{i j}+c_{i j}
$$

If the analysis is applied to employment, E, then ${ }^{2}$

$$
\begin{gathered}
d_{i j}=E_{i j}^{*}-E_{i j} \\
g_{i j}=E_{i j} r_{u s} \\
m_{i j}=E_{i j}\left(r_{i, u s}-r_{u s}\right) \\
s_{i j}=E_{i j}\left(r_{i j}-r_{i, u s}\right),
\end{gathered}
$$

where $r_{i j}, r_{i, u s}$ and $r_{u s}$ represent regional and national growth rates defined as follows:

$$
\begin{aligned}
r_{i j} & =\frac{E_{i j}^{*}-E_{i j}}{E_{i j}} \\
r_{i, u s} & =\frac{E_{i, u s}^{*}-E_{i, u s}}{E_{i, u s}}
\end{aligned}
$$




$$
r_{u s}=\frac{E_{u s}^{*}-E_{u s}}{E_{u s}},
$$

and $E_{i j}=$ employment in the $i$ th sector in the $j$ th region, $E_{i, u s}=$ employment in the ith sector in the U.S., and $E_{u s}=$ total employment in the U.S., a11 measured in a base year. The superscript "*" denotes employment in the terminal year of the analysis.

For any region the national growth (3), industry-mix (4) and competitive position (5) can be evaluated for a specific industrial sector " $i$ " or summed over al1 sectors and evaluated for the entire region. The shift-share equation for sector " $i$ " in the $j$ th region is:

$$
d_{i j}=E_{i j u s}+E_{i j}\left(r_{i, u s}-r_{u s}\right)+E_{i j}\left(r_{i j}-r_{i, u s}\right)
$$

Notice that this "classical" shift-share equation charges each regional industry with a rate of employment growth equal to that achieved by the national economy over the analysis perlod. lhe difference between the actual employment change, $d_{i j}$, and this national gruwth effecl is called the "net shift" of sector "i" in the $j$ th region. The net shift is also equal to the sum of the industry-mix and competitive effects.

The industry-mix effect (4) for the ith sector will be positive in all regions if sector "i" employment grows faster than total employment, both measured at the national level $\left(r_{i, u s}>r_{u s}\right)$. Likewise, the industry-mix effect will either vanish or turn negative if $r_{i, u s} \leq r_{u s}$. The competitive position (5) for sector " $j$ " in the $j$ th region will be positive, zero or negative depending on whether regional employment growth in this sector is faster than $\left(r_{i j}>r_{i, u s}\right)$, equal to $\left(r_{i j}=\right.$ $\left.r_{i, u s}\right)$ or slower than $\left(r_{i j}<r_{i, u s}\right)$ employment growth in this same 
industry at the national level. In addition, a positive (negative) competitive position implies that a region's share of national employment in a particular industry is increasing (decreasing) over the analysis period.

If each of the shift-share components (effects) is summed over all sectors, the sign of the resulting total net shift indicates the direction of change, if any, in the region's share of total U.S. employment. The total industry-mix effect will be positive (negative) in regions with above average proportions of employment in sectors with rapid (static or declining) growth at the national level. Likewise, the total competitive effect will be positive (negative) in regions where employment grew faster (slower) than the industry-mix or employment structure would suggest.

At this juncture it should be emphasized that shift-share analysis is no more than a measurement technique or standardization procedure for decomposing the growth of a regional variable. The method in no way purports to explain "why," for instance, the competitive effect is positive in some regions and negative in others. Thus, equation 9 should be considered an identity rather than a behavioral relationship.

\section{Two Problems with the Classical Shift-Share Equation}

The theoretical and empirical limitations of shift-share analysis are well documented and will not be considered in this paper. ${ }^{3}$ However, two of these limitations or problems inherent in the classical shiftshare equation warrant a brief description. 
A. The Problem of "Weights"

One criticism often leveled at shift-share analysis is that the technique takes no account of changes in regional industrial structure over the analysis period $[6,8,10,14,16]$. Notice in equation 9 that al1 regional and national growth rates are "weighted" by base year employment levels. Thus, when shift-share component totals are determined for a particular region, the "weights" used represent the industrial structure of the region in the base period; and no account is made of structural change between the base and terminal year of the analysis.

Dunn $[6$, p. 108] compares this problem to that of index numbers: the longer the period of analysis the larger the bias resulting from changes in the weights. Fuchs [8], and Klaassen and Paelinck [10] suggest correction methods based on "average structure" over the period of analysis. Stilwell [14] proposes a specific modification of the basic shift-share equation to directly measure the employment impacts of changing industrial structure. Finally, Ashby [1] has demonstrated that the shift-share technique is perfectly capable of utilizing any convex combination of Inlidal and les'mind values a a basc.

\section{B. The Problem of "Interwoven Effects"}

The competitive effect has been described as the dynamic element of change within the region [2, p. 19]. However, Rosenfeld [13] and others argue that the competitive effect, as defined in equation 5 , depends not only on the dynamic nature of a sector $\left(r_{i j}-r_{i, u s}\right)$, but also on the concentration of regional employment in that sector, $E_{i j}$. Thus the competitive position and industry-mix effects are interwoven, 
both depend on industrial structure. Therefore, the "classical" formulation of the competitive effect does not measure what it is often described to measure - competitive advantage and disadvantage.

A simple example will illustrate the nature of these interwoven effects. ${ }^{4}$ Assume that two regions, $a$ and $b$, have the same total employment and identical regional growth rates for sector "k" $\left(r_{k a}=r_{k b}\right)$. Thus, both regions have an identical "competitive advantage" or "disadvantage" $\left(r_{k a}-r_{k, u s}=r_{k b}-r_{k, u s}\right)$. However, the competitive position will vary $\left(c_{k a} \neq c_{k b}\right)$ if the sectoral distribution of employment (regional structure) is different in the two regions $\left(E_{k a} \neq E_{k b}\right)$. In sum, because regional structure determines the magnitude of both the industry-mix and competitive effects, the two effects are interwoven and the competitive position is an impure measure of regional competitive advantage or disadvantage.

\section{A Proposed Reformulation}

Esteban-Marquillas [7] (hereafter E-M) has reformulated or rearranged the classical shift-share equation in order to solve the latter problem of interwoven effects. This is accomplished by redefining the competitive position and creating a fourth shift-share component, the "allocation effect."

\section{A. The Revised Equation}

The revised shift-share equation is based on a new element, $\hat{E}_{i j}$, that E-M terms the "homothetic employment" in sector " $i$ " of region " $j$ ". 5 He defines this element as "the employment that sector ' $i$ ' of region ' $j$ ' would have if the structure of the employment in such a region were 
equal to the national structure" $[7, p .251]$. Stated another way, $\hat{E}_{i j}$ is the employment that region " $j$ " would have in the $i$ th sector if the "location quotient" for this sector in the region were equal to one. Thus,

$$
\hat{E}_{i j}=E_{j} \frac{E_{i, u s}}{E_{u s}} \text {, }
$$

where $E_{j}=$ total employment in the $j$ th region in the base year.

E-M utilizes homothetic employment to purge the competitive position of all regional structural influence. By substituting homothetic employment, $\hat{E}_{i j}$, for "effective employment," $E_{i j}$, the competitive position (s) becomes

$$
c_{1 j}^{\prime}=\hat{E}_{1 f}\left(r_{i f}-r_{i, u s}\right)
$$

The unexplained portion of employment change $\left(d-g-m-c^{\prime}\right)$ is called the "allocation effect" $[7$, p. 251]. For the ith sector in region " $j$ " the allocation effect, $a_{i j}$, is expressed as

$$
a_{i j}=\left(E_{i j} \quad \hat{E}_{i j}\right)\left(r_{i j}-r_{i, u s}\right) .
$$

In analyzing the meaning of the allocation effect, E-M states that this fourth shift-share component "will show us if the region is specialized in those sectors in which it enjoys better competitive advantages" [7, p. 252]. He further states that the total allocation effect "will be the larger the better [the reglon's] employment is distribuled among the different sectors, according to their respective advantages" $[7$, p. 252] 
Although the sign of the allocation effect can be either positive or negative, four possible combinations of regional specialization $\left(E_{i j}-\hat{E}_{i j}\right)$ and competitive advantage $\left(r_{i j}-r_{i, u s}\right)$ are possible. ${ }^{6}$ Thus, a region may either specialize $\left(E_{i j}-\hat{E}_{i j}>0\right)$ or not specialize $\left(E_{i j}-\hat{E}_{i j}<0\right)$ in sector " $i$ " employment, and may demonstrate, for this same industry, either a competitive advantage $\left(r_{i j}-r_{i, u s}>0\right)$ or disadvantage $\left(r_{i j}-r_{i, u s}<0\right)$. These four possibilities for the allocation effect are listed, with an identifying code number, in Table 1 .

For any region the national growth (3), industry-mix (4), revised competitive position (11) and allocation (12) effects can be evaluated for a specific industrial sector " $i$ " or summed over all sectors and evaluated for the entire region. ${ }^{7}$ The E-M reformulation of the shiftshare equation for sector " $i$ " in the $j$ th region is:

$$
\begin{aligned}
d_{i j}= & E_{i j} r_{u s}+E_{i j}\left(r_{i, u s}-r_{u s}\right)+\hat{E}_{i j}\left(r_{i j}-r_{i, u s}\right) \\
& +\left(E_{i j}-\hat{E}_{i j}\right) \cdot\left(r_{i j}-r_{i, u s}\right) .
\end{aligned}
$$

B. Analysis of Regional Employment Growth: 1960-1970

A shift-share analysis of employment change between 1960 and 1970 was undertaken to examine the regional dimensions of the revised competitive position and new allocation effects. The components in equation (13) were determined for 34 employment sectors over two spatial grids: 173 BEA economic areas and 8 BEA economic regions. ${ }^{8}$

Table 2 presents a shift-share analysis of employment change between 1960 and 1970 in a specific BEA economic area - Knoxville, Tennessee. Buth the classical (model 1) and E-M (model 2) shift-sharc 
Table 1. Possible Allocation Effects

\begin{tabular}{|c|c|c|c|c|c|}
\hline \multirow[b]{2}{*}{$\begin{array}{l}\text { Code } \\
\text { No. } \\
(1-4)\end{array}$} & \multirow[b]{2}{*}{ Definition } & \multirow[b]{2}{*}{$\begin{array}{c}\text { Allocation } \\
\text { effect } \\
\left(a_{i j}\right)\end{array}$} & \multicolumn{3}{|c|}{ Components } \\
\hline & & & $\begin{array}{c}\text { Spec-alization } \\
\left(E_{i j}-\bar{E}_{i j}\right)\end{array}$ & $\begin{array}{l}\text { Compet } \\
\text { advar } \\
\left(r_{i j}-\right.\end{array}$ & $\begin{array}{l}\text { titive } \\
\text { ntage } \\
r_{i, \text { us }}\end{array}$ \\
\hline 1. & $\begin{array}{l}\text { Competitive disadvantage, } \\
\text { specialized }\end{array}$ & - & + & & - \\
\hline 2 & $\begin{array}{l}\text { Competitive disadvantage, } \\
\text { not specialized }\end{array}$ & + & - & & - \\
\hline 3 & $\begin{array}{l}\text { Competitive advanzage, } \\
\text { not specia_ized }\end{array}$ & $\therefore$ & - & & + \\
\hline 4 & $\begin{array}{l}\text { Competitive advan:age, } \\
\text { specialized }\end{array}$ & + & + & & + \\
\hline
\end{tabular}


Table 2. Shift-Share Analysis of Employment Growth: 1960-1970, Knoxville, Tenn., BEA Economic Area

\begin{tabular}{|c|c|c|c|c|c|c|c|}
\hline \multirow[b]{4}{*}{ Industry name } & \multirow{4}{*}{$\begin{array}{l}\text { Change } \\
\text { in } \\
\text { employ- } \\
\text { ment } \\
\text { (d) }\end{array}$} & \multicolumn{6}{|c|}{ Components of employment change ${ }^{a}$} \\
\hline & & \multicolumn{3}{|c|}{ Model No. 1} & \multicolumn{3}{|c|}{ Model No. $2^{b}$} \\
\hline & & \multirow{2}{*}{$\begin{array}{l}\text { Nat. } \\
\text { growth } \\
\text { (g) }\end{array}$} & \multirow{2}{*}{$\begin{array}{l}\text { Ind. } \\
\operatorname{mix} \\
(m)\end{array}$} & \multirow{2}{*}{$\begin{array}{l}\text { Comp. } \\
\text { effect } \\
\text { (c) }\end{array}$} & \multirow{2}{*}{$\begin{array}{l}\text { Comp. } \\
\text { effect } \\
\left(c^{\prime}\right)\end{array}$} & \multicolumn{2}{|c|}{ Allocation } \\
\hline & & & & & & $\begin{array}{c}\text { Effect } \\
\text { (a) }\end{array}$ & Code $^{c}$ \\
\hline Agriculture & -13179 & 4748 & -13613 & -4313 & -3138 & -1175 & 1 \\
\hline Forestry and fisheries & 190 & 74 & -64 & 179 & 185 & -6 & 3 \\
\hline Mining & -4928 & 2239 & -2890 & -4277 & -998 & -3278 & 1 \\
\hline Contract construction & 4130 & 3651 & -1040 & 1518 & 1307 & 211 & 4 \\
\hline Food and kindred products & -1221 & 1402 & -2972 & 349 & o 369 & -20 & 3 \\
\hline Textile mill products & 995 & 2195 & -1764 & 563 & 196 & 366 & 4 \\
\hline Appare1 & 6067 & 1490 & -895 & 5471 & 3473 & 1998 & 4 \\
\hline Printing and publishing & 997 & 429 & -37 & 605 & 1316 & -710 & 3 \\
\hline Chemicals and allied products & -943 & 3474 & -490 & -3926 & -793 & -3133 & 1 \\
\hline Lumber products and furniture & 438 & 2158 & -2811 & 1091 & 434 & 657 & 4 \\
\hline Nonelectrical machinery & 1807 & 234 & 119 & 1452 & 7864 & -6411 & 3 \\
\hline Electrical equipment & 1885 & 160 & 88 & 1636 & 12323 & -10687 & 3 \\
\hline Motor vehicles and equipment & 1136 & 80 & 12 & 1042 & 8852 & -7809 & 3 \\
\hline Other transportation equipment & 474 & 62 & -7 & 418 & 5278 & -4860 & 3 \\
\hline Paper and allied products & 641 & 124 & -31 & 547 & 2059 & -1511 & 3 \\
\hline Petroleum refining & -25 & 24 & -55 & 5 & 48 & -43 & 3 \\
\hline Primary metals & 357 & 1482 & -1413 & 288 & 192 & 95 & 4 \\
\hline Fäbricated metals and ordnance & 1636 & 372 & -79 & 1342 & 37.79 & -2437 & 3 \\
\hline All other manufacturing & 2655 & 1076 & -505 & 2083 & 3541 & -1457 & 3 \\
\hline Railroad transportation & -1011 & 724 & -1877 & 141 & 148 & -6 & 3 \\
\hline Trucking and warehousing & 456 & 660 & 64 & -269 & -300 & 31 & 2 \\
\hline Other transportation & 400 & 441 & 188 & -229 & -376 & 146 & 2 \\
\hline Communications & 211 & 550 & 409 & -749 & -903 & 154 & 2 \\
\hline Public utilities & 2737 & 760 & -238 & 2214 & 2115 & 98 & 4 \\
\hline Wholesale trade & 3303 & 1490 & 1366 & 445 & 534 & -88 & 3 \\
\hline Retail trade & 5200 & 7982 & 2013 & -4796 & -4698 & -98 & 1 \\
\hline Pinance, insurance and reaî estate & $29 \% 3$ & 1211 & 1143 & 618 & 1112 & -493 & 3 \\
\hline Lodging and personal services & 1490 & 1621 & -657 & 526 & 527 & 0 & - \\
\hline Business and repair services & 1606 & 1152 & 1400 & -946 & -1080 & 133 & 2 \\
\hline Amusement and recreation services & 233 & 281 & 27 & -75 & -112 & 37 & 2 \\
\hline Private households & -2960 & 1680 & -4664 & 24 & 23 & 1 & 4 \\
\hline Professional services & 19872 & 5981 & 16233 & -2342 & -2407 & 64 & 2 \\
\hline Public administration & 2519 & 1656 & 752 & 109 & 169 & -59 & 3 \\
\hline Armed Forces & 19 & 106 & -22 & -64 & -822 & 757 & $\underline{2}$ \\
\hline Totals & 40160 & 51784 & -12313 & 688 & 40222 & -39533 & - \\
\hline
\end{tabular}

Model 1 = classical shift-share; Model 2 = Esteban-Marquillas reformulation.

$b_{\text {For model }} 2$ the national growth $(\mathrm{g})$ and industry-mix (m) effects are identical to $\mathrm{g}$ and $\mathrm{m}$ in mode1 1. Also note that $c^{\prime}+a=c$.

CAllocation codes: 1 = competitive disadvantage, specialized

2 = competitive disadvantage, not specialized

3 = competitive advantage, not specialized

4 = competitive advantage, specialized 
components are listed. For model 2 the allocation codes (1-4) defined in Table 1 are also noted.

The totals of the first four columns in Table 2 reveal the general character of employment growth in the Knoxville economic area between 1960 and 1970. The negative total industry-mix effect indicates that the Knoxville area had above average proportions of employment in sectors with subnormal growth at the national level. The positive total competitive effect indicates that employment grew faster in the Knoxville economic area than its industry-mix or employment structure would suggest. However, the negative total industry-mix effect more than offsets the positive total competitive effect resulting in a negative total net. shift $(d-g$ or $m+c)$. Thus, the Knoxville economic area grew slower than the nation and the area's share of total U.S. employment declined between 1960 and 1970 .

The classical (model 1) shift-share components can also be evaluated for the individual employment sectors listed in Table 2. Notice that the natural resource industries tended to lag while the service industries tended to lead total employment growth between 1960 and 1970 at the national level. The competitive effects (c) listed in lable 2 indicate, in general, that manufacturing employment in the Knoxville economic area increased faster than manufacturing employment at the national level. Thus, the area's share of national manufacturing employment increased between 1960 and 1970 .

Employment growth in the textile mill products and apparel industries in the Knoxville economic area has been typical of that in many southern regional economies. Although national employment in these two sectors 
increased between 1960 and 1970, employment grew slower than total national employment over this same time period. Thus, the industry-mix effect for each of these industries is negative. On the other hand, the positive competitive effects for these two sectors in Table 2 indicate that employment in the textile mill products and apparel industries in the Knoxville area grew faster than at the national level. Thus, the area exhibited a competitive advantage $\left(r_{i j}-r_{i, u s}>0\right)$ in these two' industries. However, the classical shift-share (model 1) analysis does not tell us if the Knoxville economic area has "exploited" this competitive advantage. Little insight is provided on regional industrial specialization.

The E-M (model 2) shift-share analysis attempts to fill this void through the "allocation" effects listed in Table 2. Examples of each possible type of allocation effect (Table 1) can be found within the employment structure of the Knoxville economic area. For example, the Knoxville area is shown to have been specialized in both textile mill products and apparel, employment sectors in which the region had a competitive advantage (code 4 ). The positive competitive effects for the manufacturing sectors have already been noted. However, because regional employment was not specialized in the majority of these industries, the allocation effects for Knoxville are negative (code 3 ). Furthermore, while the Knoxville area had a competitive disadvantage in both the agricultural and trucking and warehousing industries, employment was specialized in the former (code 1) but not the latter (code 2). 
Table 3 lists the signs of the net shift, industry-mix, competitive position and allocative effects for total employment change between 1960 and 1970 in the eight BEA economic regions. ${ }^{9}$ Note that of the eight economic regions listed, only the Great Lakes region has a positive total allocation effect. ${ }^{10}$ A corresponding examination of the total allocation effects for the smaller BEA economic areas shows that only 6 of the 173 areas had positive total allocation effects between 1960 and 1970.11

Since positive allocation effects imply "correct" regional structure (see Table 1) an obvious question is: Why have so few areas of the United States had an employment distribution consistent with regional competitive advantage and disadvantage? The following section will demonstrate that the inference of seemingly irrational regional economic behavior, as measured by the allocation effect, is an inherent property of the E-M shift-share equation (13).

\section{The Problem of Weights Once Again}

As stated, the weights, $E_{i j}$, in the classical shift-share equation (9) represent regional employment structure in the base period and no account is made of structural change between the base and terminal year of the analysis. In the revised shift-share equation (1.3) the weights used in conjunction with the allocation effect, $E_{i j}-\hat{E}_{i j}$, represent the difference between "effective" and "homothetic" employment. Again, the weights are defined in base year values and no account is made of structural change over the period of analysis. 
Table 3. Shift-Share Analysis of Total Employment Growth: 1960-1970, for Eight BEA Economic Regions

\begin{tabular}{lcccc}
\hline & \multicolumn{5}{c}{ Components of employment change } \\
\cline { 2 - 5 } \multicolumn{1}{c}{ Regions } & $\begin{array}{c}\text { Net } \\
\text { shift } \\
(\mathrm{d}-\mathrm{g})\end{array}$ & $\begin{array}{c}\text { Industry } \\
\text { mix } \\
(\mathrm{m})\end{array}$ & $\begin{array}{c}\text { Competitive } \\
\text { position } \\
\left(\text { c or c } \mathrm{c}^{\prime}\right)\end{array}$ & $\begin{array}{c}\text { Allocation } \\
\text { effect } \\
(\mathrm{a})\end{array}$ \\
\hline New England & - & + & - & - \\
Mideast & - & + & - & - \\
Great Lakes & - & + & - & - \\
Southeast & + & - & + & - \\
Plains & - & - & + & - \\
Southwest & + & - & + & - \\
Rocky Mountain & + & - & + & - \\
Far West & + & + & & - \\
\hline
\end{tabular}

*Insignificant . 
The question of appropriate weights for the allocation effect represents a serious problem for the empirical implementation of the E-M shift-share equation. Notice that the substitution of terminal year for base year weights in the classical shift-share equation (9) will alter the "magnitude" of the various growth components; while this same substitution in the revised equation (13) may change the "sign," and thus the interpretation, of the allocation effect. 1 ?

Changing employment structure may cause a sign change in the classical shift-share specification, but only in the case where the components are summed over all employment sectors and evaluated for an entire region. On the other hand, one would expect sign changes in the allocation effect for individual sectors to occur as a direct result of changing employment structure over the period of analysis. For example, a sector defined as "not specialized" in the base year $\left(E_{i j}-\hat{E}_{i j}<U\right)$ may become "specialized" in the terminal year $\left(E_{i j}^{*}-\hat{E}_{i j}^{*}>0\right)$. Combined with a measure of regional competitive advantage or disadvantage $\left(r_{i j}-r_{i, u s}\right)$ that is independent of the "weight problem," the net result is a change in both the sign and interpretation of the allocation effect for this employment sector.

The change in the allocation effect that results from the subslitutioin of terminal year for base year weights in (12) is equal to

$$
\left[E_{i j}^{*}-\hat{E}_{i j}^{*}-\left(E_{i j}-\hat{E}_{i j}\right)\right]\left(r_{i j}-r_{i, u s}\right)
$$

After rearrangement, the terms within the brackets in (14) represent the change in effective (actual) employment, $d$, less the change in homothetic (expected) employment between the base and terminal years of 
the analysis. Thus, for $r_{i j}-r_{i, u s}>0$, the substitution of terminal year for base year weights will cause the allocation effect to increase (decrease) if the change in actual employment is greater than (less than) the change in expected employment. For certain regions and employment sectors this change in magnitude of the allocation effect will be accompanied by a change or switch in sign.

In order to assess the sensitivity of the sign of the allocation effect to changes in regional industrial structure, the allocation component (12) of the E-M shift-share equation was alternately computed with base year and terminal year specialization weights. This sensitivity of the allocation effect sign was examined for 34 employment sectors in 173 BEA economic areas over two time periods: 1950-1960 and 1960-1970. The results are listed in Table 4.

Two specific types of sign change resulted. In terms of the code numbers and allocation effect components listed in Table 1, these were a change from code 1 to code 2 :

$$
r_{i j}-r_{i, u s}<0 ; E_{i j}-\hat{E}_{i j}>0 ; E_{i j}^{*}-\hat{E}_{i j}^{*}<0 \text {, and }
$$

a change from code 3 to code 4 :

$$
r_{i j}-r_{i, u s}>0 ; E_{i j}-\hat{E}_{i j}<0 ; E_{i j}^{*}-\hat{E}_{i j}^{*}>0 \text {. }
$$

In both cases the sign of the allocation effect changes from negative to positive implying a "correct" redistribution of employment specialization consistent with regional competitive advantage and disadvantage.

Table 4 lists, for each time period and each industrial sector, the number of BEA economic area allocation effects that switch from code 1 to code 2, and from code 3 to code 4 . Notice that the greatest number of switches occurred between 1950 and 1960 in the business and repair 
Table 4. Sensitivity of the Allocation Effect; by Industrial Sectors (No. of BEA economic area allocation effects that change sign when specialization weights change)

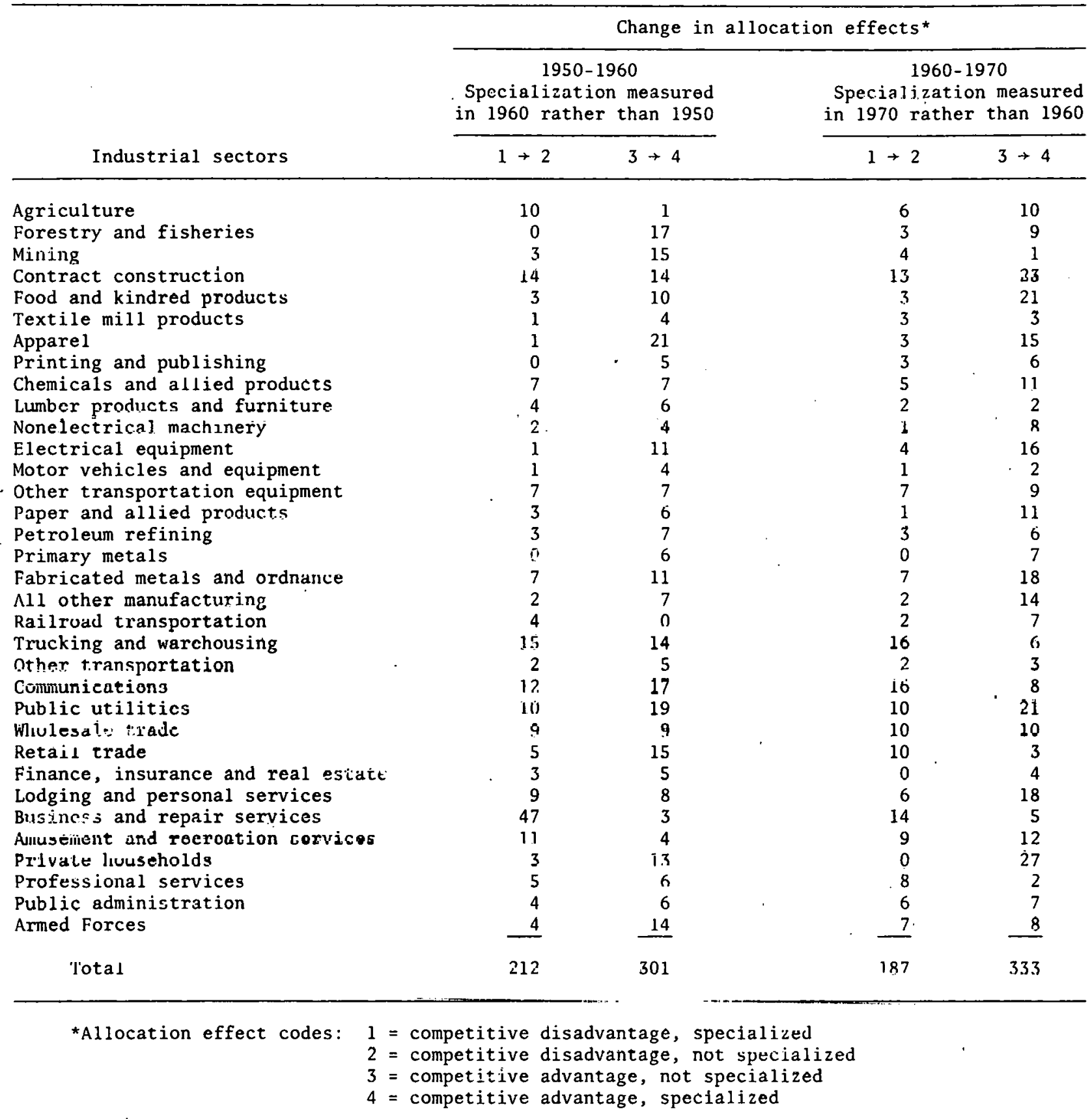


services industry. Using this industry as an example, the sign of the allocation effect changes from negative to positive in 50 ( 29 percent) of the BEA economic areas as a result of structural change between 1950 and 1960.

Computer-printed maps were generated on the BEA economic area grid in order to examine the spatial dimensions of the allocation effect and the sensitivity of this effect to changes in regional industrial structure between 1960 and 1970. Figures 1 and 2 provide this information for the 171 contiguous BEA economic areas for two employment sectors: fabricated metals and ordnance, and public utilities, respectively. The allocation effects are classified and displayed on the basis of the four component codes listed in Table 1, and are determined with both 1960 (map A) and 1970 (map B) specialization weights. Notice the scarcity and concentration of the BEA economic areas with both a competitive advantage and a specialization in either of these two industries in Figures 1-A and 2-A; this is less evident in Figures $1-\mathrm{B}$ and 2-B.

For either industry (Figure 1 or 2) a comparison of maps A and B provides an indication of the allocation effect sensitivity to changes in regional employment structure between 1960 and 1970. Many of the BEA economic areas with a competitive advantage that do not specialize in 1960 do specialize in $1970 .^{13}$ Because the sign of the allocation effect changes from negative in map A to positive in map B for many BEA economic areas located in the central (Figure 1) or southeastern and plains (Figure 2) regions of the U.S., the economic behavior of these regions appears to have been more rational; they did tend to specialize their growth in sectors for which they had competitive advantages. 
(A) 1960 Specialization Weights

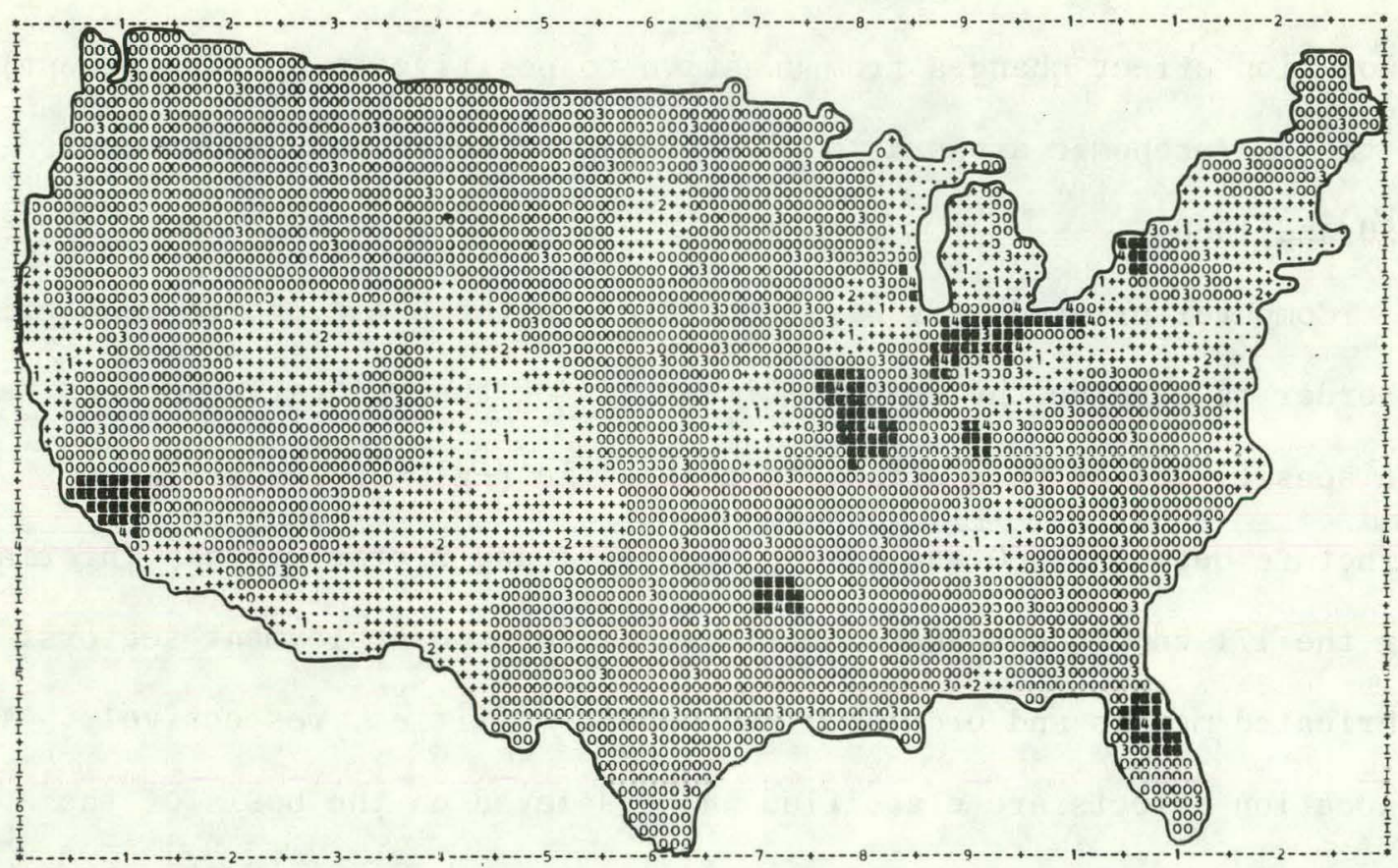

(B) 1970 Specialization Weights
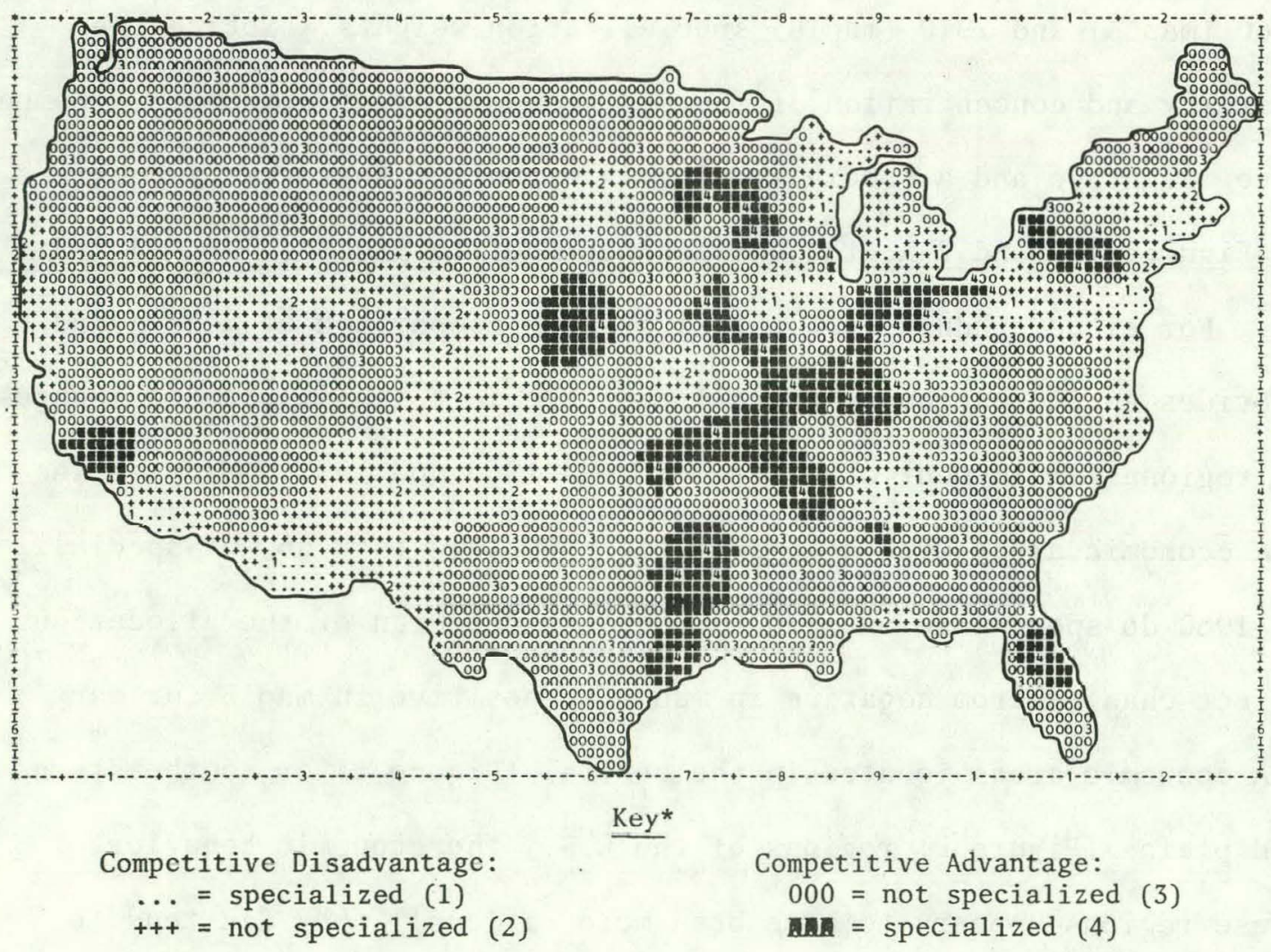

Fig. 1. Allocation Effects in the Fabricated Metals and Ordnance Industry: 1960-70*. 
(A) 1960 Specialization Weights

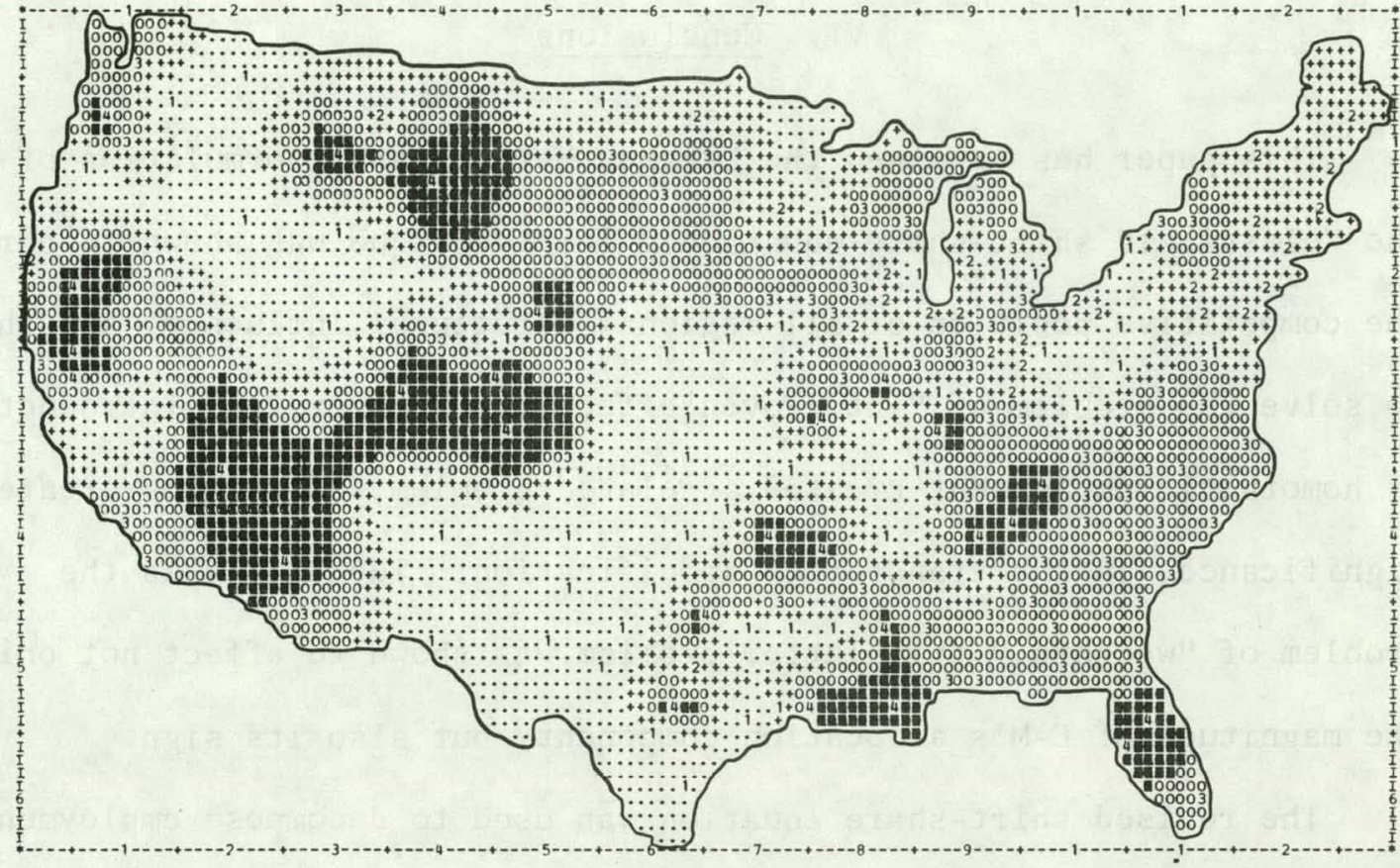

(B) 1970 Specialization Weights

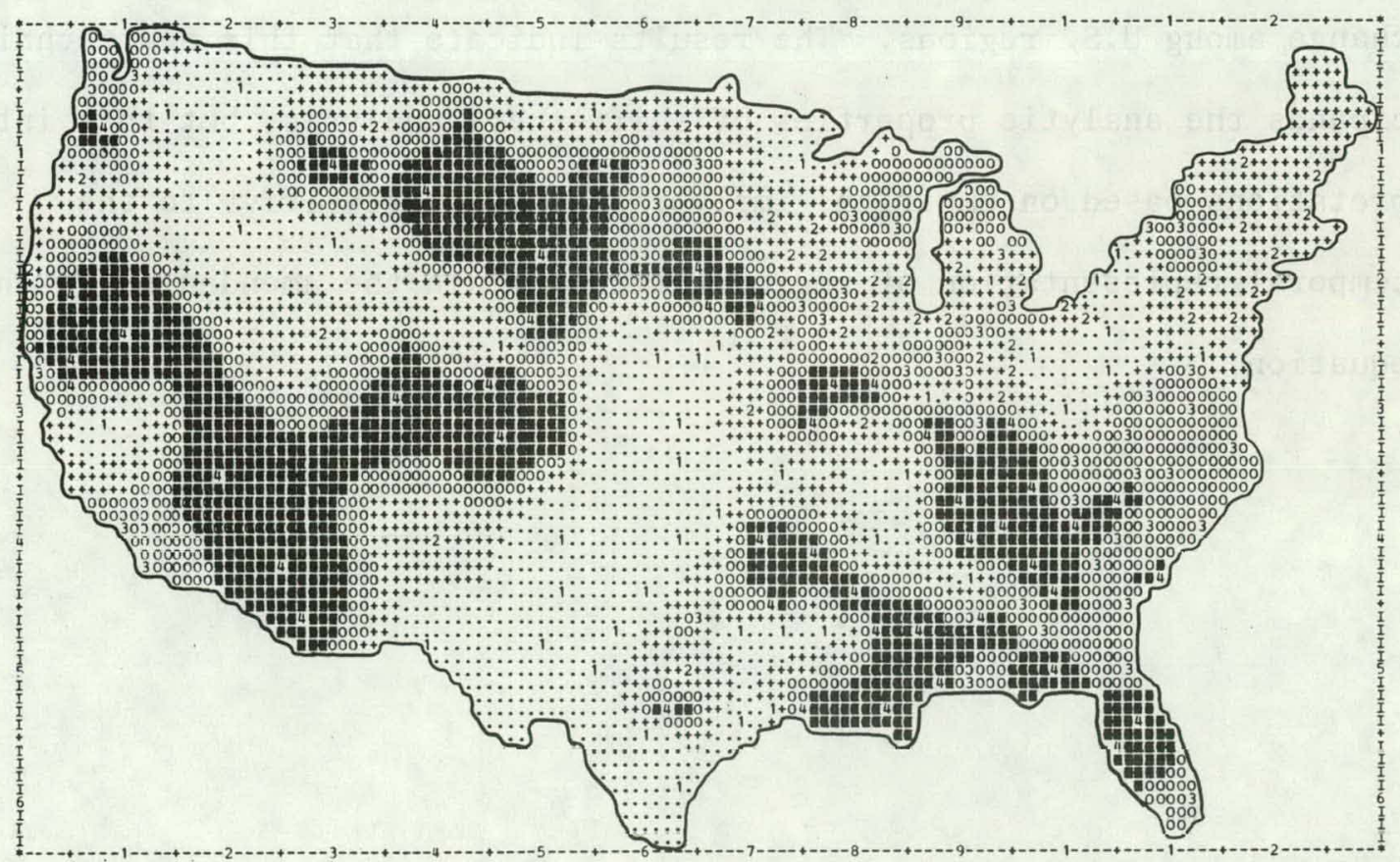

Competitive Disadvantage:

$\ldots$ = specialized (1)

Key*

$+++=$ not specialized $(2)$

Competitive Advantage: $000=$ not specialized $(3)$

ํ. specialized $(4)$

Fig. 2. Allocation Effects in the Public Utilities Industry: $1960-70 *$. 


\section{Conclusions}

This paper has examined the Esteban-Marquillas reformulation of the "classical" shift-share equation. The technique was shown to purge the competitive position of all regional structural influence, and thus to solve the problem of "interwoven effects." However, the introduction of homothetic employment created a related problem, of perhaps greater significance, in the transformed specification. Identified as the problem of "weights," this latter problem was shown to affect not only the magnitude of E-M's allocation component, but also its sign.

The revised shift-share equation was used to decompose employment growth between 1960 and 1970 into four effects that measure differential change among U.S. regions. The results indicate that this new technique expands the analytic properties of shift-share analysis, but that interpretations based on empirical implementation are sensitive to the temporal representation of regional structure in the amended shift-share equation. 
$\underline{\text { Notes }}$

1. The shift-share literature varies on terminology. The national growth effect is also termed the share effect, the industry-mix effect is also named the compositional mix or proportionality shift, and the competitive position effect is sometimes called. the differential shift or regional share - thus the name "shift and share analysis" $[2,6,8,12]$.

2. Employment is used as the regional variable throughout the paper.

3. For an excellent discussion of these limitations see $[3,9,14]$. Other limitations are related to the use of shift-share analysis in regional economic forecasting $[4,5,11]$.

4. This example was employed by Esteban-Marquillas [7, p. 250] to illustrate this same problem.

5. This paper examines the first, and more interesting, of two shiftshare reformulations proposed by E-M [7, pp. 251, 252].

6. The case of a null allocation effect $\left(E_{i j}-\hat{E}_{i j}=0\right)$ and/or $\left(r_{i j}-r_{i, u s}=0\right)$ is not considered.

7. However, region to region summability of the revised components, a desirable property of the classical shift-share equation, no longer works. The authors thank Lowell Ashby for pointing out this analytical deficiency of the E-M reformulation.

8. For an excellent discussion on the delineation of boundaries of, and structural changes in, the $173 \mathrm{BEA}$ economic areas, see [15].

9. Employment in these large regions was approximated by summing over constituent BEA economic areas.

10. Actually, the effect is insignificant for it represents 300 employees out of a total employment change in this region of approximately 2.5 million.

11. Rochester, New York; Lansing, Michigan; Fort Wayne and Indianapolis, Indiana; and Cincinnati and Columbus, Ohio. Al1 of these BEA economic areas fall within the Great Lakes economic region except Rochester which is part of the Mideast region.

12. Concomitant changes are required in the specification of (9) and (13) to ensure that the components in each equation sum to $d_{i j}$.

13. The reverse is true for BEA economic areas with competitive disadvantages in Figure 1 or 2 . 


\section{$\underline{\text { References }}$}

1. Ashby, L. D., "Changes in Regional Industrial Structure: A Comment," Urban Studies, $\underline{7}$ (3) 298-304, 1970.

2. _L "The Geographical Redistribution of Employment: An Examination of the Elements of Change," Survey of Current Business, 44(10) $13-20,1964$.

3. "The Shift and Share Analysis: A Reply," Southern Economic Journal, $34(3) 423-425,1968$.

4. Bruwu, H. I., "Shiff and Share Projections of Regional Economic Growth: An Empirical Test," Journal of Regional Science, 9, 1-18, 1969.

5. "The Stability of the Regional Share Component: Reply," Journal of Regional Science, 11(1) 113-114, 1971 .

6. Dunn, E. S., Jr., "A Statistical and Analytical Technique for Regional Analysis," Papers and Proceedings of the Regional Science Association, 6, 97-112, 1960 .

7. Esteban-Marquillas, J. M., "A Reinterpretation of Shift-Share Analysis," Regional and Urban Economics, 2(3) 249-255, 1972.

$\dot{8}$. Fuchs, V. R., "Changes in the Location of U.S. Manufacturing since $1929, "$ Journal of Regional Science, I(2) 1-17, 1959.

9. Houston, D. B., "The Shift and Share Analysis of Regional Crowth: A Critique," Southern Economic Journal, 33(4) 577-581, 1967.

10. Klaassen, L. H., and J. H. P. Paelinck, "Asymmetry in Shift and Share Analyșis," Regional and Irrban Fronnmics, 2 (3) 256..261, 1972.

11. Paraskevopoulos, Christo C., "The Stability of the Regional Share Component: $\Lambda$ n Empirical l'est," Journal of Regional Science, 11 (1) $107-112,1971$.

12. Perloff, H. S., E. S. Dunn, Jr., E. E. Lampard, and R. F. Muth, Regions, Resources and Economic Growth, Baltimore: The Johns Hopkins Press, 1960.

13. Rosenfeld, F., "Commentaire à l'expose de M. Dunn," Economic Appliqueé, 1, $531-534,1959$.

14. Stilwel1, F. J. B., "Regional Growth and Structural Adaptation," Urban Studies, 6(2) 162-178, 1969. 
15. "The BEA Economic Areas: Structural Changes and Growth, 1950-73," Survey of Current Business, 55(11) 14-25, 1975.

16. Thirlwa11, A. P., "A Measure of the Proper Distribution of Industry," Oxford Economic Papers, 46-58, March 1967.

17. U.S. National Resource Planning Board, Industrial Location and Natural Resources, Chapter 4, Washington, D.C., 1943. 
THIS PAGE

\section{WAS INTENTIONALLY \\ LEFT BLANK}


ORNL/TM-5918

\section{INTERNAL DISTRIBUTION}

1. S. I. Auerbach

2. S. E. Beall

3. L. G. Berry

4. C. R. Boston

5. B. H. Bronfman

6. A. A. Brooks

7. C. A. Burwell

8. R. S. Carlsmith

9. W. S. Chern

10. J. T. Cowan

11. C. G. Crafton

12. F. L. Culler

13. R. M. Davis

14. R. C. DeVault

15. J. E. Dobson

16. W. Fulkerson

17. H. H. Herzog

18. E. A. Hirst

19. N. E. Hink1e

20. R. B. Honea

21. D. G. Jacobs

22. D. L. Kaserman

23. C. R. Kerley

24. M. J. Ketelle

25. A. S. Loeb 1

26. L. A. Martin

27. J. R. McWherter
28. J. W. Miche1

29. C. S. Oen

30. D. C. Parzyck

31. E. B. Peelle

32. H. Postma

33. B. J. Purdy

34. P. L. Rice

35. C. R. Richmond

36. M. W. Rosentha1

37. T. H. Row

38. R. M. Rush

39. M. A. Shields

40. R. L. Spore

41. R. E. Thoma

42. R. I. Van Hook

43. A. H. Voelker

44. D. P. Vogt

45. H. E. Zittel

46- 47. Central Research Library

48. Document Reference Section

49- 50. Laboratory Records

51. Laboratory Records - RC

52. ORNL Patent Office

53-147. Regional Economic Analysis Group Regional and Urban Studies Section Energy Division

\section{EXTERNAL DISTRIBUTION}

148. Director, Research and Technical Support Division, ERDA-ORO.

149-175. Technical Information Center, ERDA-ORO.

176-300. Regional and Urban Studies Distribution, Energy Division. 